\title{
Original Study
}

\author{
Karin Ojala*, Carl-Gösta Ojala
}

\section{Northern Connections: Interregional Contacts in Bronze Age Northern and Middle Sweden}

\author{
https://doi.org/10.1515/opar-2020-0104 \\ Received June 10, 2019; accepted April 7, 2020
}

\begin{abstract}
This article examines northern connections in the Nordic Bronze Age, focusing on interregional contacts in middle and northern Sweden. In the article, we argue that it is important to incorporate a northern perspective in the discussions about the Scandinavian Bronze Age and its networks. We focus on the Mälaren Valley region, especially the province of Uppland, and the northern parts of Sweden, in particular the coastal areas of northern Sweden. We discuss some aspects of the archaeological material, which have been used in earlier discussions of interregional contacts in middle and northern Sweden during the Bronze Age, such as the Håga mound outside of Uppsala, and burial cairns and bronze artefacts in northern Sweden. Furthermore, we discuss eastern contacts with areas in present-day Finland and Russia, and how these have been interpreted in middle and northern Sweden. In our view, there is a need to critically examine interregional contacts and the construction of regional entities and borders in the Bronze Age. In order to better understand the relations between north and south, it is necessary to critically examine the research history behind the present-day conceptions of regions and borders, as well as the political dimensions and power relations involved.
\end{abstract}

Keywords: Bronze Age, Uppland, Northern Fennoscandia, Håga mound, Mälar axes, Ananino axes

\section{Introduction}

The Mälaren Valley in middle Sweden, and especially the province of Uppland, is located in the northern part of what is usually seen as the Nordic Bronze Age sphere (Figs. 1, 2). In 20th-century research, notions of connections with southern Scandinavia have had great importance for the views of the Bronze Age within the Mälaren Valley region (see e.g. Almgren, 1905; Ekholm, 1921). Further to the north, in northern Sweden and Northern Fennoscandia (a geographical term incorporating the northern parts of Norway, Sweden, Finland and the north-westernmost part of Russia), the archaeological material from the Bronze Age period has been interpreted in a different way than in middle Sweden and Uppland. The northern coastal region, on the one hand, has usually been connected with the Mälaren Valley and middle Sweden. The northern inland area, on the other hand, has often been viewed as an area with a different cultural tradition during the Bronze Age, more influenced by connections with areas in northern Finland and in Russia.

The aim of this article is to examine interregional contacts in northern Sweden and middle Sweden during the Bronze Age, and how these contacts have been discussed in earlier research. We examine this topic primarily from a research historical perspective. One starting point for our study is that northern Sweden and middle Sweden during the Bronze Age have largely been studied separately, and that there is need for more research exploring relations and connections between north and south. Another point of

\footnotetext{
*Corresponding author: Karin Ojala, Department of Archaeology and Ancient History, Uppsala University, Box 626, Uppsala, 75126, Sweden, E-mail: karin.ojala@arkeologi.uu.se

Carl-Gösta Ojala, Department of Archaeology and Ancient History, Uppsala University, Box 626, Uppsala, 75126, Sweden
} 
departure is that ideas about eastern contacts, with areas in present-day Finland and Russia, have had great importance in earlier studies of northern and middle Sweden in the Bronze Age. However, the development and foundation of these ideas have not been examined more in-depth. A third issue is that political contexts and dimensions, in several ways, have influenced the construction of Bronze Age regions and borders in middle and northern Sweden. With our study, we wish to address these issues and contribute to the understanding of how notions of the northern European Bronze Age, its regions and borders, have emerged and developed in research over time.

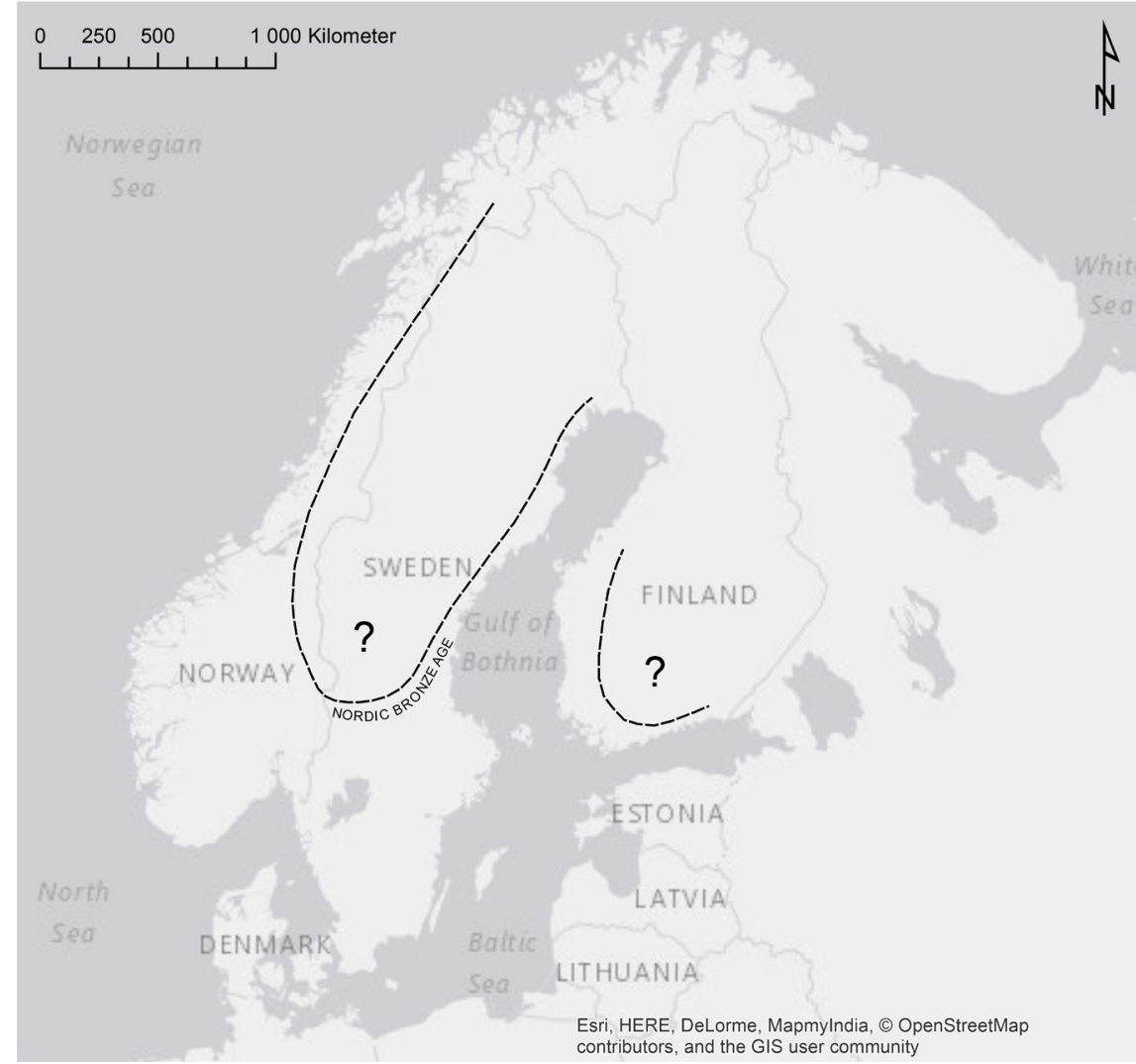

Figure 1: Map showing the approximate northern border of the Nordic Bronze Age sphere, as it has traditionally been conceptualized in archaeological research. We argue that it is important to critically examine the construction of regions and borders in the Bronze Age in middle and northern Sweden. From Skandfer \& Wehlin (2017, p. 308).

This article focuses on the Mälaren Valley region (the regions surrounding the Lake Mälaren), especially the province of Uppland which is located in the north-eastern part of the Mälaren Valley, and the northern parts of Sweden (which are located north of Uppland), especially the coastal area (Fig. 2). We argue that it is important to incorporate a northern perspective in the discussions about the Scandinavian Bronze Age and its networks. In order to better understand the contact networks in middle Sweden, there is a need to look not only towards the south, but also to the north and the east.

Here, we discuss some aspects of the archaeological material which has been used in earlier discussions of interregional contacts in Bronze Age middle and northern Sweden, mainly from a research historical perspective. As a symbol of the Uppland Bronze Age and its connections with southern Scandinavia, we especially focus on the Bronze Age site at Håga, Uppsala. In northern Sweden, we mainly focus on the coastal region and certain aspects of the archaeological material, in particular burial cairns and bronze artefacts.

We argue that it is important to critically examine the construction of regions and borders in the Bronze Age, as well as to critically analyze interregional contacts. The relations between the Mälaren Valley and 
the northern parts of Sweden have not been studied in the same extent as other contact networks and have not been attributed the same importance for middle Sweden compared to the southern contacts. In order to gain a deeper understanding of the relations between north and south in the Bronze Age, it is necessary to critically examine the research history behind the present-day conceptions of the Bronze Age regions and borders, and to acknowledge the complexities and political dimensions involved.

The question about relations between northern Sweden and middle Sweden is complicated and connected with discussions about relations between the inland and coastal zones in the north, as well as discussions about the construction of cultures and identities in prehistory. On the one hand, the understanding of prehistory, including the Bronze Age and the Early Iron Age, in northern Sweden has been closely connected with views on the history of the Indigenous Sámi population, which has been a much-contested topic over time in Sweden and the other Nordic countries. On the other hand, Uppland has been considered as the historical heartland of the early Swedish state (Svearike) and has occupied a central place in the national narrative of Sweden. Therefore, the geographical border between middle and northern Sweden is a border with a complex and multidimensional history.

In this article, we use the concept of "Bronze Age" as a chronological concept for the period ca. 1700500 B.C. (1700-1100 for the Early Bronze Age, and 1100-500 for the Late Bronze Age), in middle as well as northern Sweden. However, in Northern Fennoscandia other chronological terms have often been used by scholars, such as "Early Metal Age", in order to emphasize the different cultural phases, and the specific material culture, in the northern areas (see e.g. Baudou, 1995, p. 52; Lavento, 2009; Arntzen, 2015, p. 4).

\section{Constructing Bronze Age Regions and Interregional Connections}

In archaeology, questions about how people have moved and travelled, and how objects, innovations, thoughts and ideas have spread across large geographical areas during prehistoric times have been, and still are, of great importance. In Scandinavian Bronze Age studies, views on regional and long-distance contacts have played an important role for the archaeological interpretations of prehistoric societies. The interest in studying contacts and interaction in prehistory has increased during recent years, with several works dealing with interregional contacts and interaction during the Bronze Age, focusing e.g. on networks of exchange and trade, social relations, technologies, and religious and ritual ideas and practices (see Kristiansen, 1998; Kristiansen \& Larsson, 2005; Alberti \& Sabatini, 2013; Rowlands \& Ling, 2013; Earle et al., 2015; Kristiansen \& Suchowska-Ducke, 2015; Suchowska-Ducke et al., 2015; Ojala, 2016; Vandkilde, 2016; Ling et al., 2018; Ling et al., 2019).

Various artefacts, in particular bronze objects, in Scandinavia demonstrate that there have been networks of contact between people, resulting in the transfer of metals, objects, ideas and knowledge over long distances. In this article, "connections" is a central concept, which covers contacts and interactions of many different kinds between people in different areas. It is important to emphasize that contacts and interactions are multifaceted and multidimensional cultural, social, economic and religious phenomena, also involving power relations between individuals and groups of people. How contacts and interactions were materialized cannot be explained simply by determining directions of influences or defining areas of origins - more complex approaches are needed.

When studying northern Scandinavia, there are challenges in characterizing and defining what the Bronze Age actually means and what cultural and economic dimensions and expressions it encompasses. What is the Bronze Age? What is connected, and what is dis-connected, in the construction of the northern spheres of the Bronze Age in Sweden? What is inside, and what is outside?

When discussing these issues, it is important not to forget the political dimensions and the power relations involved in archaeological research. The early history of archaeology in Sweden was closely connected with the emergence of the modern Swedish society (Jensen, 2002; Baudou, 2004; Goldhahn, 2005). Throughout the early modern and modern periods (from the early 17 th century onwards), northern Sweden has largely been treated as a resource area for the central power in middle Sweden (Ojala, 2018; 
Ojala \& Nordin, 2015, 2019). This structural relation still has a strong effect today on social and economic relations within Sweden, and has deeply influenced the structures of Swedish archaeology. Through much of the history of Swedish archaeology, northern Sweden has to a large extent been reduced to a resource colony, providing different natural resources to middle Sweden (Loeffler, 2005). Here, hierarchical thinking, connected with views on the Sámi population and Swedish colonialism in the north, has played a central role. In the case discussed in this article, concerning interregional contacts in middle and northern Sweden during the Bronze Age, the contacts and influences have mostly been seen as a one-way communication, from the south to the north, as part of this hierarchical thinking. However, there are no reasons to assume that influences did not go in both directions, and that the interregional interaction in prehistoric times was much more complex than earlier thought.

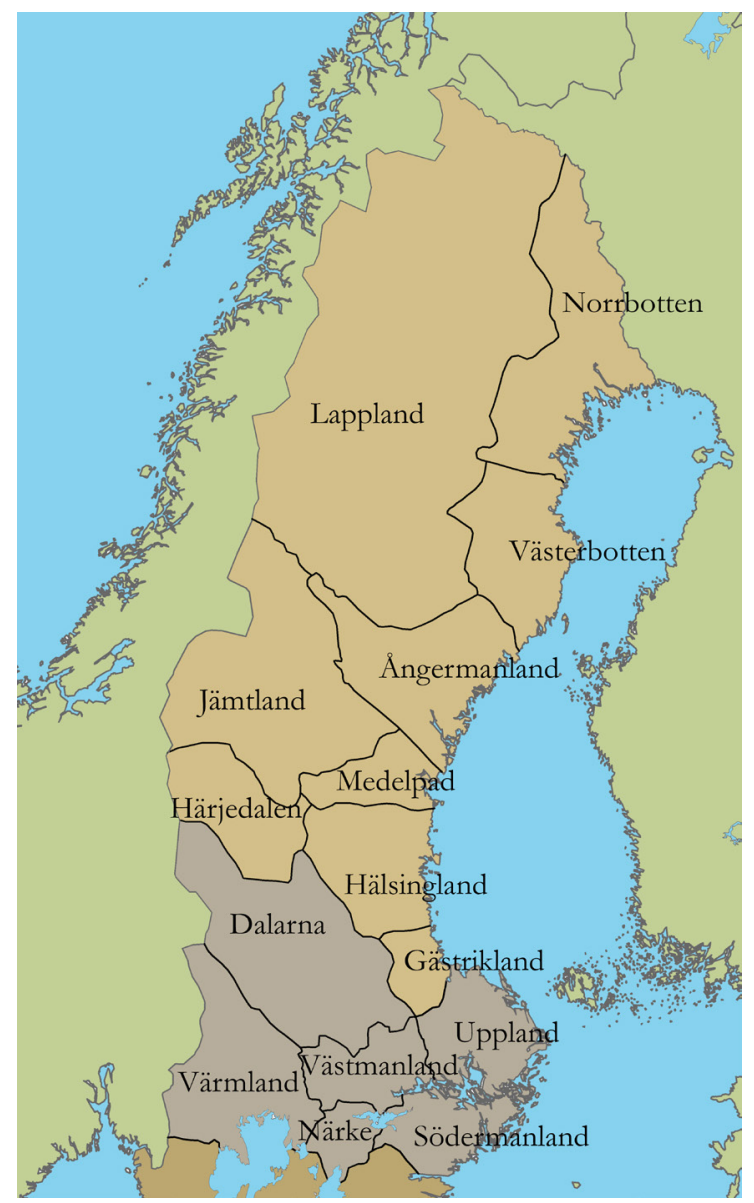

Figure 2: Map showing the provinces of northern and central Sweden. The lighter (brown) areas are northern Sweden or Norrland, the darker (gray) areas are middle Sweden or Svealand. Map by authors.

Although the present-day state boundaries did not exist in prehistoric times, these boundaries have in many ways influenced the ways in which the past has been studied. Differences in political situations and archaeological traditions need to be considered when studying archaeology across national borders. This is especially relevant when discussing archaeology in Northern Fennoscandia, where the current state boundaries to a large extent have affected and delimited the understanding of prehistory in the area. This is also the case when discussing contacts in middle and northern Sweden with areas in present-day Russia, where the political situation in the 20th century, with the "Iron Curtain", has restricted contact and interaction between researchers and institutions from the different countries. 


\section{Connecting Bronze Age Uppland}

As mentioned above, Uppland in the northern Mälaren Valley region has in earlier archaeological research often been considered as a northern periphery or northern edge of a Nordic Bronze Age region. Sometimes, also large areas of the northern Swedish coastal zone have been seen as part of this area, or at least profoundly influenced by it (see discussions in Baudou, 1995; Forsberg, 2012; Ojala, 2016). However, this is a complicated question which has been much debated (see further discussion below).

For a long time, researchers have underlined the importance of regional variations within the Nordic Bronze Age area (see e.g. Ekholm, 1921, p. 68; Thedéen, 2004; Victor, 2007; Anfinset \& Wriggelsworth, 2012; Ojala, 2016). Many of the different bronze artefacts and several categories of prehistoric remains found in Uppland have parallels in southern Scandinavia. However, there are also several regional differences, for instance the large quantity of heaps of fire-cracked stones in Uppland, variations in burial customs, differences in pottery tradition and the distribution pattern of Mälar axes (Jaanusson, 1981; Victor, 2007; Thedéen, 2004; Eriksson, 2009). One explanation for these regional variations in the archaeological material that has been put forward by researchers is that Uppland had contact networks which extended towards the east. It is therefore important to study networks stretching in many geographical directions, in order to understand the north-eastern Mälaren Valley during the Bronze Age.

In the following, we will look at two important Bronze Age sites in Uppland which were investigated during the first decade of the 20th century, two cairns in Torslunda and one mound in Håga (Almgren, 1905; Ekholm, 1921, p. 13-17; see Fig. 3). At both of these sites, excavated graves contained artefacts with southern parallels, and both sites have been of great importance for the interpretation of Uppland's Bronze Age and in discussions on the relations of the Mälaren Valley with areas further to the south.

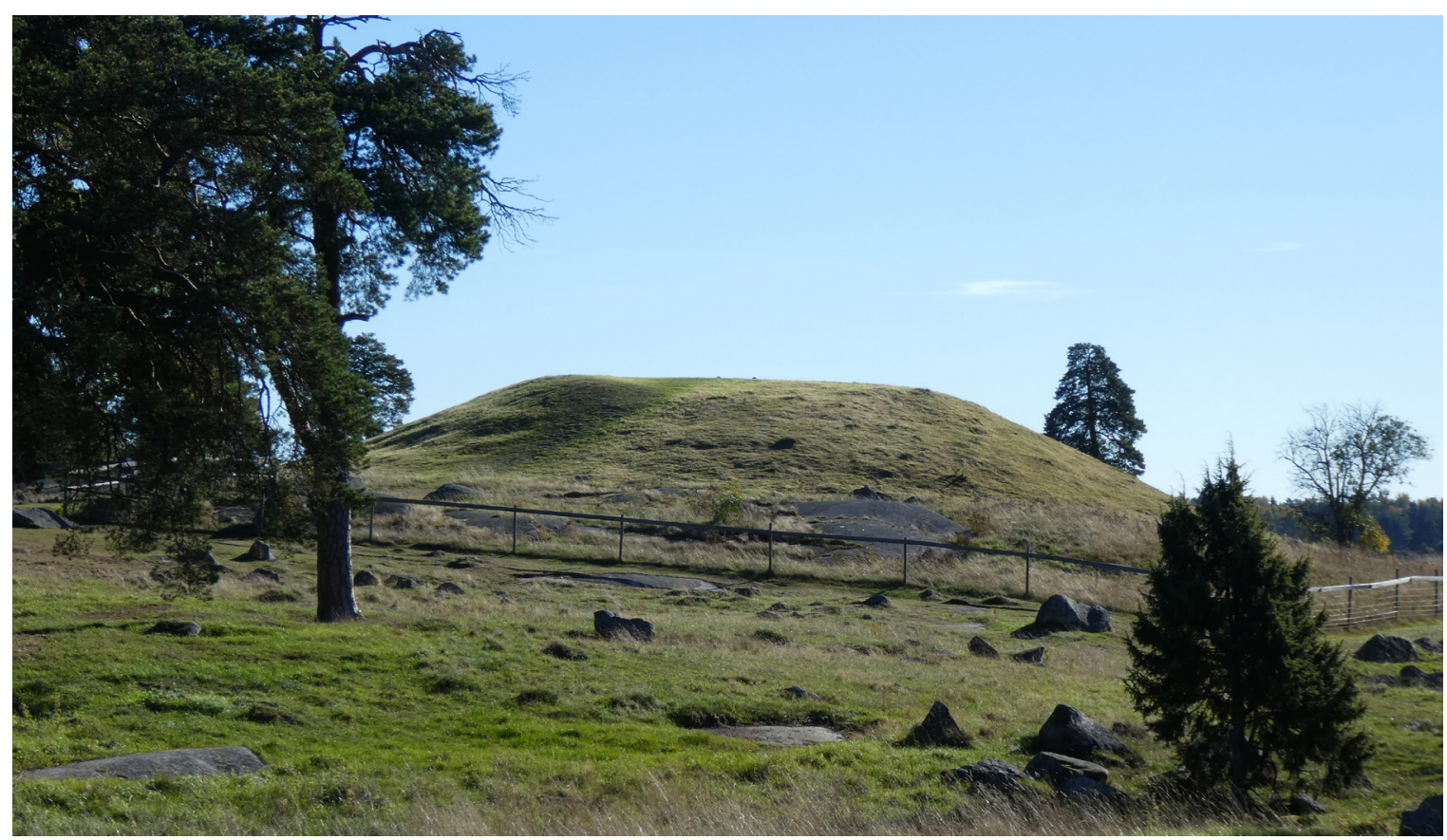

Figure 3: The Late Bronze Age mound at Håga, Uppland. The Håga mound has been a symbol for the southern connections of the Bronze Age period in Uppland. Photo by authors.

The graves at Torslunda and Håga were excavated at a point in time when very little was known about the Bronze Age in this region. Although some bronze artefacts had been discovered in middle and northern Sweden, these finds were very few in numbers in comparison with the southern parts of Scandinavia (see Montelius, 1871-1873, p. 173). There were no known Bronze Age settlement sites in Uppland, only a few 
sites with rock art had been discovered, and the knowledge about the region's burial customs was almost non-existent. Therefore, bronze artefacts and their distribution patterns became very important for the interpretation of the period in the area (see e.g. Almgren, 1905; Montelius, 1917; Ekholm, 1921). When the mound at Håga and the cairns in Torslunda were investigated during the early 20th century, only two other graves from the Bronze Age were known in Uppsala (Almgren, 1905, p. 45). The lack of other known graves is probably one of the reasons why the Håga mound and the Torslunda cairns became so central for the interpretations of Uppland's Bronze Age. Another reason was probably that both of the graves contained several bronze artefacts. Along with some of the other known bronze artefacts (Montelius, 1871-1873; Ekholm, 1921, p. 12), they served as the foundation for the image of the southern contacts of Uppland, which has lived on until today.

Håga, in the outskirts of today's Uppsala, is perhaps the place which is most commonly associated with the Bronze Age in Uppland. During the Bronze Age, Håga was strategically located by important water courses. The most well-known prehistoric remains at the Håga site is the large earthen mound, which was excavated in the early 20th century. Before the investigations of the large mound, it had been thought of as an Iron Age mound, similar with the large mounds at Gamla Uppsala (Stenberger, 1964, p. 210). Instead, objects found during the excavations showed that the mound were from Montelius period IV. The mound is, as far as we know today, in many ways unique with its northern location, but the environment around the mound is quite typical for the area, with heaps of fire-cracked stones and so-called cult houses (Victor, 2002; Kaliff \& Oestigaard, 2018). There is also a hill fort that has been dated to the Bronze Age in the Håga Valley close to the Håga mound (Olausson, 1995).

Although the mound became a symbol for Uppland's Bronze Age, there have been relatively few studies devoted to it. There have been several archaeological investigations in the Håga area (Olausson, 1995; Victor, 2002), but the mound itself has not been much studied since the excavations in the early 20th century. However, in recent years the Håga mound has once more become the object of research (Kaliff \& Oestigaard, 2018; Ullén \& Drenzel, 2018).

The mound was constructed with grass turf over a large stone cairn. In the stone cairn there were traces of a timber construction, possibly a chamber, which had contained an oak coffin. In the burial, which contained cremated bones, there were also many bronze artefacts such as a sword, a brooch, buttons, razors, tweezers and small bronze fragments and gold spirals (Almgren, 1905). Although there were similarities between the Håga finds and artefacts found in southern Sweden, it was mainly in Denmark that similar objects had been discovered in larger quantities. The Danish connection received a lot of attention, and the interpretation was that Uppland had been strongly influenced by Denmark during this time period (Almgren, 1905, p. 47). The origins of the objects found in the grave, and whether some such as the sword and especially the brooch might have been locally produced, have been debated (see Lindqvist, 1913; Ekholm, 1921, p. 35, 69; Oldeberg, 1933, p. 76; Ullén \& Drenzel, 2018).

Another issue has concerned the individual buried in the mound. It has earlier been debated whether the person buried in the mound was a person coming from southern Scandinavia, which could have explained the difference in burial customs in comparison with other known graves in the area. However, new analyses of the cremated bones show that an individual aged between 40-60 years old was buried in the mound, and that this individual most likely had been brought up in the eastern parts of the Mälaren Valley (Ullén \& Drenzel, 2018, p. 133).

The Håga mound was not the only burial in the area which was seen as evidence of contacts with areas further to the south. A couple of years after the excavations at Håga, two stone cairns were excavated further north in Uppland in Torslunda, Tierp parish. Several bronze objects were discovered in, and outside of, one of the cairns. The objects, including a neck collar, a miniature dagger, a double button, two tuteli as well as six pendants, date the grave to the Early Bronze Age. The six pendants in the grave have been considered to originate from areas south of the Baltic Sea (Ekholm, 1921, p. 17). It has been suggested that the grave could be interpreted as a burial for a woman who had come from southern Scandinavia (Bergerbrant, 2007, p. 121). Interestingly, a hoard from the Early Bronze Age has been discovered in the same area (Ekholm, 1921).

During the early 20th century, several researchers considered that the Late Bronze Age had been a “Golden Age” in the Mälaren Valley region (see e.g. Ekholm, 1921, p. 48; Arbman, 1934, 1938; Nerman, 1954). 
The Håga mound became an important symbol for a flourishing Late Bronze Age in the region, especially in Uppland. In contrast to the Early Bronze Age, many researchers viewed the Mälar Valley as an important center during the Late Bronze Age. In the researchers' view, the relations with southern Scandinavia could not explain the "boom" in Mälardalen. Instead, eastern contacts were considered to have been an important factor in the Late Bronze Age expansion (Ekholm, 1921, pp. 68-72; Nerman, 1954).

The "southern" bronze objects found in the area, as well as the Håga mound and the Torslunda cairn, have been very important for how the area has been perceived in research. However, there has, since the early 20th century, also existed a different thread of thinking, which has pointed to the specific regional material expressions in the Mälaren Valley and the differences in the archaeological material between the Mälaren Valley and southern Scandinavia (see e.g. Arbman, 1938, p. 84; Thedéen, 2004; Victor, 2007, p. 252; Eriksson, 2009). Sometimes the Mälaren Valley has been promoted as its "own" region or as a central area with its "own" networks stretching in different directions, not least towards the east, including areas across the Baltic Sea and further east in Russia (Ekholm, 1921, p 70, Nerman, 1954; Hjärthner-Holdar, 1993; see also Ojala, 2016, and further discussion below). The question of interaction with areas in the east has thus been closely connected with questions about regional differences within the Nordic Bronze Age sphere (see e.g. Ekholm, 1921, p. 72).

During the 20th century, the knowledge about the Bronze Age in the Mälaren Valley has greatly increased. Many burial sites, mounds of fire-cracked stones and settlements have been registered and some of them have been excavated. Furthermore, about 470 sites with figurative rock art and about 1830 sites with cup marks have been discovered in the southern parts of Uppland (which have been recently discussed by Ling, 2013). In recent years, several new archaeological excavations, for instance in connection with the large-scale project of building the new E4 highway north of Uppsala, have led to much new knowledge about the Bronze Age period in Uppland (see e.g. Forsman \& Victor, 2007; Hjärthner-Holdar, Eriksson \& Östling, 2008; cf. discussion in Ojala, 2016).

\section{Northern Fennoscandia in the Bronze Age Networks}

Northern Fennoscandia, of which northern Sweden is a part, is a vast geographical area with great variation in landscapes, vegetation and climate. Prehistory in the northern parts of Sweden (or Norrland, 'The northern lands') has in much of earlier archaeological research been treated as something separate and different in relation to the southern parts of the country (see e.g. Ekholm, 1941; Christiansson, 1963; cf. discussions in Broadbent, 2001; Loeffler, 2005; Ojala, 2009; Hagström Yamamoto, 2010). An important aspect is the relative lack of archaeological investigations in northern Sweden. Larger archaeological excavations are rare, and huge areas in northern Sweden have never been surveyed by archaeologists - in stark contrast with the southern parts of the country.

Northern Fennoscandia is also the traditional settlement area of the Indigenous Sámi people. The traditional core settlement area of the Sámi population is called Sápmi in North Sámi language (Sábme in Lule Sámi, Saepmie in South Sámi). Sápmi stretches across the nation state boundaries between northern Norway, Sweden, Finland and the Kola Peninsula in the Russian Federation. Archaeology in northern Sweden has been much more controversial than in the southern parts of the country, with connections to academic debates about the possibilities of ethnic interpretations based on archaeological material, as well as present-day conflicts over land and cultural rights, including conflicts over the exploitation of natural resources, such as mining, in Sápmi (see Ojala, 2009, 2014, 2019; Ojala \& Nordin, 2015).

The question concerning prehistoric relations between north and south in Sweden is a complex issue, which is connected with current understandings of the relationships between "Swedish" and "Sámi" culture and identity through time, as well as views on early modern and modern Swedish colonial history in Sápmi (see discussions in Ojala, 2009, 2014, 2017, 2018; Hagström Yamamoto, 2010; Ojala \& Nordin, 2015, 2019). Throughout much of the history of archaeology, Sámi culture and identity have been constructed as the "Other", in opposition to the ideas of national Swedish, Norwegian or Finnish identity and culture. Until recently, Sámi archaeology has been a quite marginalized topic within Nordic archaeology. However, 
in recent decades a field of Sámi archaeology has developed in the northern parts of Norway, Sweden and Finland (see further Ojala, 2009; Hansen \& Olsen, 2014).

In the northern parts of Sweden, especially along the coast, several bronze objects, defined as south Scandinavian, have been discovered (Bakka, 1976; Larsson, 2017). Along the coast there are also a large number of stone cairns which usually are associated with the middle parts of Sweden. The coastal area of northern Sweden, with burial cairns and "south Scandinavian" objects, has often been described as part of, or heavily influenced by, the Nordic Bronze Age area, and several scholars have viewed large parts of northern Sweden as a periphery in a cultural and economic system with a center in southern Scandinavia or middle Sweden (see e.g. Kristiansen, 1987; Baudou, 1989).

However, there are also other perspectives which underline contacts with and influences from several different areas, in the south and the east, as well as "independent" internal developments within the northern Swedish areas. Hans Bolin has argued that a division between northern and southern Sweden has been reified, as the eastern aspects of, for instance, pottery and bronze objects have been emphasized in northern Sweden, and at the same time downplayed in middle Sweden (Bolin, 2005, p. 219). In recent decades, scholars have discussed regional and interregional contacts in Northern Fennoscandia, concerning different prehistoric periods, emphasizing dynamic internal developments in the northern communities, but with concurrent interaction with the outside world (see e.g. Ramqvist, 2007; Damm, 2012a, 2012b; Kuusela et al., 2018).

One important question has thus been how much contact there has been between the "north" and the "south", and to what extent the coastal areas in northern Sweden have been affected by influences from middle Sweden. Are there so great similarities between middle Sweden and the northern Swedish coast, and are the differences between inland and coast in the north so distinct, that one can consider the coastal area as part of the Nordic Bronze Age sphere?

The question about the coastal area's relation to middle Sweden is closely connected with the question about the relation between coast and inland in northern Sweden. This is a complicated issue which has been much debated for a long time (see e.g. Hallström, 1942, 1949; Christiansson, 1963; Baudou, 1968, 1989; Bolin, 1999; Forsberg, 1999, 2012). In earlier research, two main models of interpretation have been applied concerning the relationship between the coastal area and the inland area. Either as a common cultural system which involves both the inland and coastal regions (with "internal" regional variation), or as a cultural dualism with two different cultural systems. Some researchers have considered that the archaeological material shows evidence of two different cultures in the coastal and inland areas. This idea has been connected with the notion of two different economic systems, where people in the inland were hunter-gatherers and the people along the coast were farmers, leading to interpretations that the inland hunter-gatherers represented the ancestors of the present-day Sámi population and that the coastal farmers represented the ancestors of the present-day Swedish population (cf. discussions and critiques of this view in e.g. Bolin, 1999, p. 98; Broadbent, 2010; Forsberg, 2012; Kuusela, 2013; Damm \& Forsberg, 2014; Kuusela et al., 2018). In Norway, there have been similar long-standing scholarly discussions on cultural dualism, regional differences, ethnic identities and relations during this time period (see Amundsen, 2017a, 2017b).

\section{Connections Between Middle and Northern Sweden}

In earlier discussions on the relations between middle and northern Sweden, burial cairns and finds of bronze objects have mainly been studied. Although stone cairns and bronze artefacts have been of central importance in earlier discussions, there are many other categories of prehistoric remains and artefacts which need to be considered in discussions on northern connections. For example, this could include settlement remains, rock art, heaps of fire-cracked stones, pottery and stone artefacts. The issue of the relationships of the rock art traditions in the north and in the south has recently been discussed by several scholars. The rock art tradition in Northern Fennoscandia is in general earlier than the southern Scandinavian rock art tradition, predominantly from the Stone Age but also partly from the Bronze Age (Gjerde, 2010; Skoglund et al., 2017; Fahlander, 2018). 


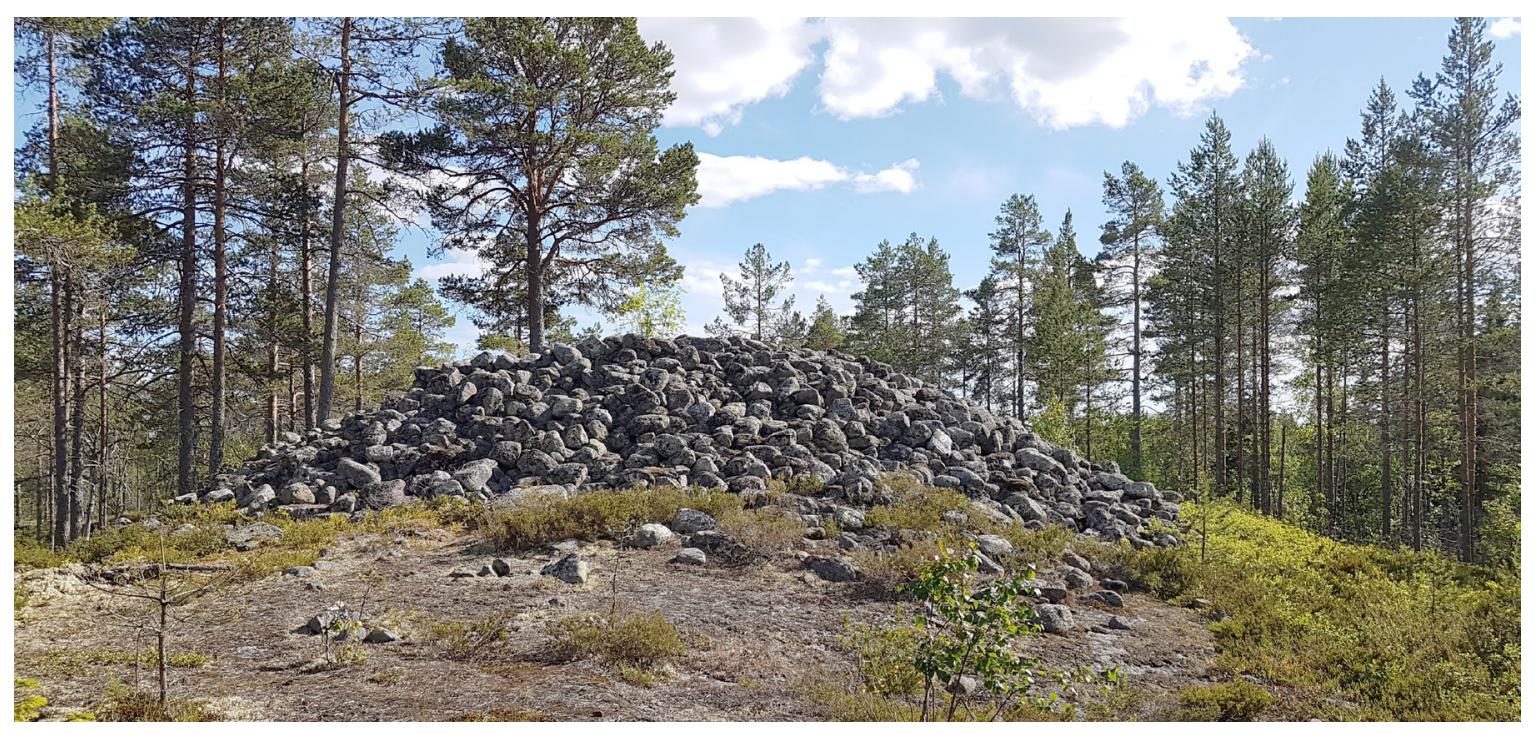

Figure 4: A stone cairn along the coast of northern Sweden, located south of Umeå in the province of Västerbotten. Photo by authors.

Burial cairns exist both in middle and southern Sweden (Thedéen, 2004; Hermodsson, 2015; Wehlin, 2017) and along the northern Swedish coast (Hallström, 1924, 1949; Baudou, 1959, 1968; Forsberg, 1999; Eriksson, Persson, \& Ulfhielm, 2008; Ramqvist, 2017; Holm \& Larsson, 2018; Persson, 2018; Fig. 4). There are also cairns along the Finnish coast on the eastern side of the Gulf of Bothnia (Tuovinen, 2002; Holmblad, 2010, pp. 56ff.; Kuusela, 2013, pp. 39ff.), and along the Norwegian Atlantic coast (Engedal, 2010). The burial cairns are generally difficult to date, and artefacts which are possible to date have only been recovered in a few cases (Baudou, 1959; Stenberger, 1964; Forsberg, 1999; Holm \& Larsson, 2018). The cairns have often been dated through their relation to the changing prehistoric shoreline. In recent years, some new C-14 datings of burial cairns have been conducted, and the results indicate that the shoreline dating can be problematic and that the chronology of the cairns can be more complex than earlier assumed (Ramqvist, 2017, p. 107; Palmbo, 2019). The distribution of cairns along the coast has been one important reason why the inland and coastal areas in northern Sweden often have been described as "belonging" to two different cultures (Bolin, 1999, p. 171). There has been a long-lived discussion about the coastal cairns and what they represent, and how they have related to the burial cairn traditions in middle and southern Sweden. Who built the burial cairns, and what relation did these people have with people in middle Sweden and in the inland areas of northern Sweden?

Considering the vast size of northern Sweden, the number of bronze objects are very few in comparison with the southern parts of the country (Larsson, 1986). Today, about 43 metal objects dated to the Bronze Age are known in northern Sweden, with 21 from the Early Bronze Age and 22 from the Late Bronze Age (Larsson, 2017; see Fig. 5 and Table 1). The bronze objects have mainly been found along the coast, but there are also a number of finds discovered in the inland. 


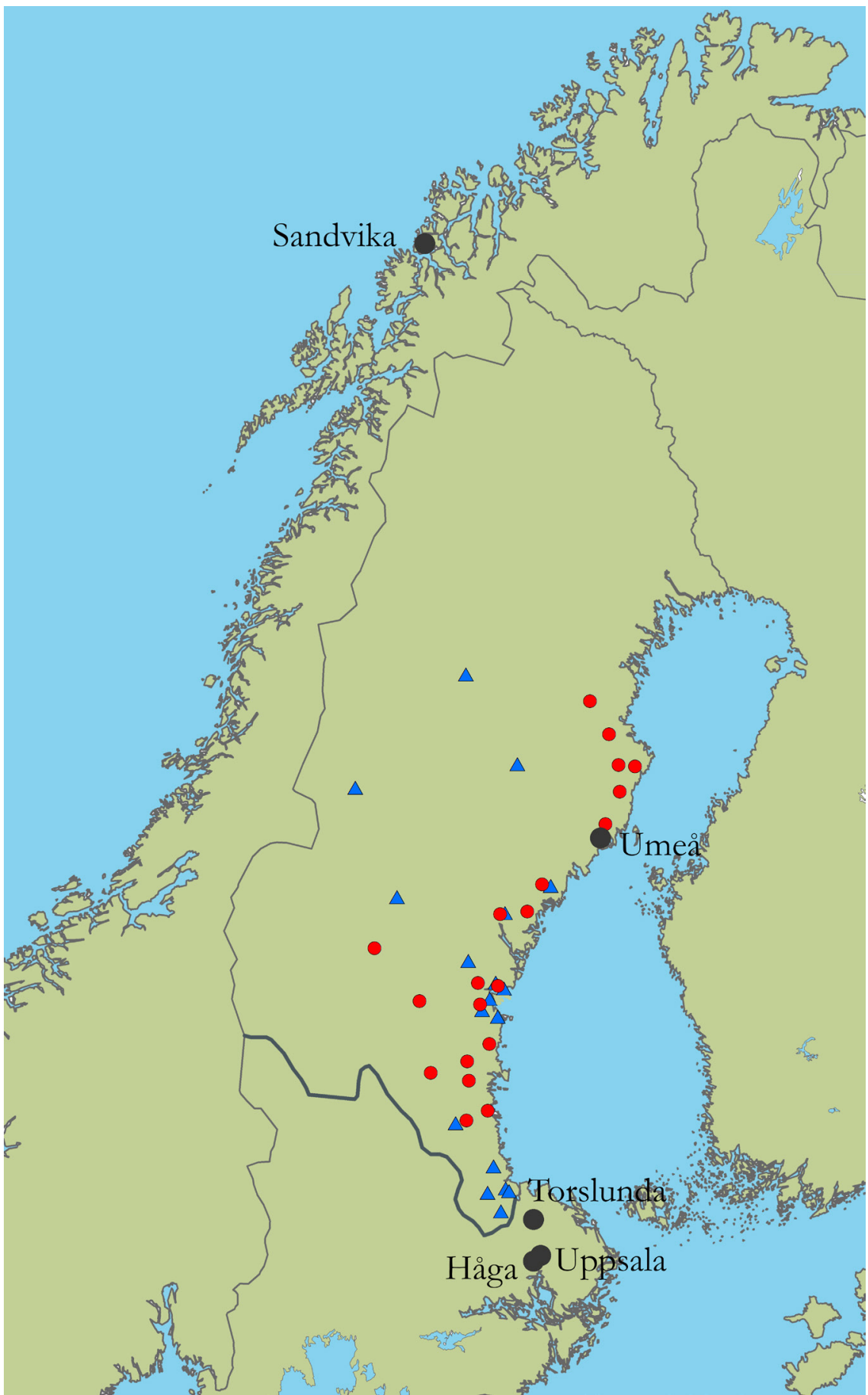

Figure 5: Map showing the location of sites mentioned in the article and the distribution of known bronze artefacts from the northern part of Sweden. Red dots represent bronze objects from the Early Bronze Age. Blue triangles represent bronze objects from the Late Bronze Age. Based on information from Larsson (2017, p. 4, 32). Map by authors. 
Table 1: Bronze artefacts found in northern Sweden, dating from the Early and Late Bronze Age. Based on information from Larsson (2017).

\begin{tabular}{|c|c|c|c|c|}
\hline Object & Site & Parish & Province & Dating \\
\hline Dagger & Prästsjödiket & Umeå & Västerbotten & EBA (I) \\
\hline Dagger & Stavre & Revsund & Jämtland & EBA (I) \\
\hline Flanged axe & Lunde & Timrå & Medelpad & EBA (I) \\
\hline Flanged axe & Mörtebo & Skog & Hälsingland & EBA (I) \\
\hline Dagger & Hökmark & Lövånger & Västerbotten & EBA (I-II) \\
\hline Spearhead & Parteboda, Hästholmen & Borgsjö & Medelpad & EBA (I-II) \\
\hline Dagger & Norra Sandnäs & Delsbo & Hälsingland & EBA (I-II) \\
\hline Belt plate & Flarken & Nysätra & Västerbotten & EBA (II) \\
\hline Pin & Frötuna, Nysvedberget & Ljustorp & Medelpad & EBA (II) \\
\hline Tutulus & Norrbo Skans & Bjuråker & Hälsingland & EBA (II-III) \\
\hline Fibula & Södra Åkulla & Jörn & Västerbotten & EBA (III) \\
\hline Socketed axe & Kusmark & Skellefteå & Västerbotten & EBA (III) \\
\hline Pin & Broträsk & Lövånger & Västerbotten & EBA (III) \\
\hline Socketed axe & Tjärn & Själevad & Ångermanland & EBA (III) \\
\hline Socketed axe & Åviken (Åvike bruk) & Hässjö & Medelpad & EBA (III) \\
\hline Axe & & Färila & Hälsingland & EBA (III-IV?) \\
\hline Sword/dagger & Sund & Vibyggerå & Ångermanland & EBA \\
\hline Dagger & Björkå & Överlännäs & Ångermanland & EBA \\
\hline Spiral & Strömma & Harmånger & Hälsingland & EBA \\
\hline Pin and spiral & Ringnäs, Ängbo & Söderala & Hälsingland & EBA \\
\hline Socketed axe & Bovik & Årsunda & Gästrikland & EBA \\
\hline Socketed axe & Billsta & Själevad & Ångermanland & LBA (IV) \\
\hline Socketed axe & Öster-Flygge & Liden & Medelpad & LBA (IV) \\
\hline Razor & Röklan & Alnö & Medelpad & LBA (IV) \\
\hline Double stud and tweezers & Knaperåsen & Gävle (tidigare Valbo) & Gästrikland & LBA (IV) \\
\hline Socketed axe & & Hedesunda & Gästrikland & LBA (IV) \\
\hline Arrowhead & Bodumsjön & Bodum & Ångermanland & LBA (V) \\
\hline Neck ring & Fullsjön & Borgvattnet & Jämtland & LBA (V) \\
\hline Socketed axe & Lögdö & Hässjö & Medelpad & LBA (V) \\
\hline $\begin{array}{l}\text { Sword/dagger, socketed axe } \\
\text { and knife }\end{array}$ & Mon (Kubikenborg) & Skön & Medelpad & LBA (V) \\
\hline Sword & Å by, Hummelviksberget & Njurunda & Medelpad & LBA (V) \\
\hline Socketed axe & Viken & Alfta & Hälsingland & LBA $(V)$ \\
\hline Socketed axe (Ananino) & Råstrand & Sorsele & Lappland & LBA (VI) \\
\hline Socketed axe (Ananino) & Bågaträsket & Lycksele & Lappland & LBA (VI) \\
\hline Sword (Hallstatt) and dagger & Stöndarbrännan & Boteå & Ångermanland & LBA (VI) \\
\hline Socketed axe & Totra kastalruin & Hamrånde & Gästrikland & LBA \\
\hline Socketed axe & Östanbäck & Gävle (tidigare Valbo) & Gästrikland & LBA \\
\hline Socketed axe & & Sandviken & Gästrikland & LBA \\
\hline Socketed axe & Myckeläng & Tynderö & Medelpad & LBA \\
\hline
\end{tabular}


Artefacts from the Early Bronze Age have mostly been found in the coastal area between Skelleftea and Söderhamn. In the provinces of Härjedalen, Lappland and Norrbotten there are no known bronze objects from the Early Bronze Age (Larsson, 2017, p. 5). The northernmost known bronze artefact from the Early Bronze Age in Sweden is part of a fibula which was found as a stray find in Jörn parish in the province of Västerbotten. Most likely the fibula is of a southern Scandinavian (Danish) type, which is very uncommon in Sweden north of the province of Skåne (Larsson, 2017, p. 6). Another interesting find from Västerbotten is a belt plate which was discovered in connection with the digging of the foundation of a barn. It seems that the belt plate was not part of a burial. The northern location of this find is unique. Other finds of belt plates are from Denmark, Skåne and southern Norway (Larsson, 2017, p. 13-14). It has been pointed out that the quality of the work does not have the same standard as the Danish and Skåne parallels. It has been suggested that perhaps it is a local craftsman with less experience who has made the belt plate (Ekholm, 1941, p. 152; Stenberger, 1964, p. 311; see discussion in Larsson, 2017, p. 14).

Late Bronze Age artefacts have mostly been registered in the provinces of Gästrikland and Medelpad. Among other bronze objects from the Late Bronze Age one can mention a Hallstatt sword, probably originating from Central Europe, which was found by a large rock in Boteå in the province of Ångermanland (Larsson, 2017, p. 39).

Another category of interesting finds are the two so-called Ananino axes, which have been found in the inland province of Lappland in northern Sweden. One of the axes was discovered in Lycksele parish in 1871, the other in Sorsele parish in 1926 (Larsson, 2017, pp. 33-34). These are the only known bronze objects from the province of Lapland. These types of axes are usually connected with the Ananino cultural area in the Volga-Kama region in Russia. Moulds for these types of axes have also been found in the northern parts of Sweden (Bakka, 1976). It is interesting that the only other find of an Ananino axe in Sweden comes from Uppland (see further below).

A few objects of possible northern character or origin have been found in the Mälaren Valley and southern Sweden, such as pottery and stone artefacts. One can mention a few shards of asbestos-tempered ceramics from the Late Bronze Age that have been found in the well-known sites in Broby (Börje parish) and Darsgärde (Skederid parish), Uppland. A few shards are also known from other parts of the Mälaren valley (Schönbäck, 1959; Eriksson, 2009, p. 104; Ojala, 2016). At the Bronze Age site of Broby, there is a large amount of stone-settings and heaps of fire-cracked stones, and also several so-called "cult houses" of the stonefoundation type. The site exhibits a varied burial custom with cremation and inhumation graves. There is also a large amount of pottery, including a large frequency of striated pottery (which has been discussed as being part of an eastern tradition) and some shards of asbestos-tempered ceramics. The asbestos-tempered pottery is significantly different from the other known pottery in the area, mostly because of the asbestostempering but also because the exterior surface of the shards is covered with so-called imitated textile pattern (Schönbäck, 1959; Jaanusson, 1981, p. 50; Ojala, 2016). Asbestos ceramics with textile impression or imitated textile impression are part of cultural traditions in the northern parts of Sweden, as well as in areas to the east (Hulthén, 1991; Lavento, 2001). This also exemplifies the problem of determining northern or eastern contacts in the area. One can also mention finds of bifacial arrowheads of quartzite, relating to a northern technological tradition, from the Mälaren Valley region, for instance from the Bronze Age site of Sommaränge skog, Viksta parish, Uppland (see Holm, Olsson, \& Weiler, 1997, p. 230; Apel \& Darmark, 2007; Falkenström, 2007, p. 203).

The distribution patterns of the different objects, and what these patterns might mean, has been much debated. These discussions have also related to the issue of the relationship between the inland and coastal regions of northern Sweden (se e.g. Bolin, 1999; Forsberg, 2012). The distributions of the different objects have been discussed in an important study by Egil Bakka (1976) and recently by Thomas B. Larsson (2017). Of course, not only finds of bronze artefacts in the northern part of Sweden, but also for instance stone objects and pottery, are of relevance in discussions about contacts between north and south. For example, there are about 30 stone axes from the Bronze Age of south Scandinavian character in middle northern Sweden (Baudou, 1995, p. 102).

Recently, new archaeological investigations along the coast in northern Sweden have produced more detailed knowledge about the Bronze Age in the region. Earlier, traces of Bronze Age settlement sites 
with long houses, as in the Mälaren Valley region, have not been found in the northern parts of Sweden. Nor were pottery of southern Scandinavian type, or casting moulds for southern Scandinavian artefacts, known in the northern areas (Baudou, 1995, p. 102). During the early 2010s, however, the first traces of long houses of southern Scandinavian type were discovered in the coastal region of Västerbotten. In connection with the construction of a new road outside of Umeå in Västerbotten, traces of several long houses were encountered. The remains of long houses at the sites of Klockarbäcken and Sockenvägen were the first north of Uppland. The settlement site at Klockarbäcken could be dated to the transition between the Early and Late Bronze Age. The settlement site at Sockenvägen was somewhat later and could be dated mainly to the Late Bronze Age (Lindqvist \& Granholm, 2016). At Klockarbäcken and Sockenvägen asbestos ceramics of a northern type as well as pottery of a southern Scandinavian type were found (Heinerud \& Larsson, 2013). The results from these new investigations are of great importance. It is obvious that the conventional images of northern Swedish Bronze Age, as well as the relations between the Mälaren Valley region and the northern Swedish coastal region, need to be reconsidered and critically re-examined.

Recent archaeological research in northern Norway has also made it apparent to rethink many of the earlier interpretations of the Bronze Age in the north. The discovery and excavation of a Bronze Age settlement site with strong connections with the Nordic Bronze Age sphere, Sandvika on Kvaløya Island, in Troms County in northern Norway, dated to the Late Bronze Age, has further complicated the image (Arntzen, 2015; Jensen \& Arntzen, 2016). At the site, remains from a three-aisled long house of south Scandinavian type were excavated, along with finds of asbestos-tempered ceramics, fragments of soapstone vessels, a bronze casting mould for a type of socketed axe dated to periods V-VI, seal and fish bones as well as bones from domesticated animals (sheep/goat). While Sandvika is the northernmost known settlement site with connections with the southern Bronze Age area, Johan Arntzen also discusses other sites in Troms County which potentially could contain settlement traces of the same kind (Arntzen, 2015). In order to prove this, more investigations are needed. As in northern Sweden and northern Finland, large-scale archaeological excavations of Bronze Age remains are low in frequency in northern Norway. In recent years, there have also been discussions among Finnish archaeologists on the character of the Bronze Age cultures in the coastal zones of northern Finland (see e.g. Holmblad, 2010; Lavento, 2012; Kuusela, 2013).

\section{Eastern Connections in Northern and Middle Sweden}

In northern Sweden, as well as in the Mälaren Valley region in middle Sweden, objects that have been considered to be either of eastern character or being related to areas in the east have been discovered. Two types of bronze axes, the so-called Mälar axes and Ananino axes (see Fig. 6), are especially interesting because they exhibit great resemblance with bronze axes from the Volga-Kama region in Russia, where large amounts of axes have been excavated at different burial grounds (see e.g. Tallgren, 1916, 1937; Meinander, 1985; Hjärthner-Holdar, 1993, 1998; Kuzminych, 1993, 1996; see further discussions in Ojala, 2016). In earlier studies of the Late Bronze Age and the earliest Iron Age in both the Mälaren Valley and northern Sweden, contacts and interaction with areas in the east have been important in archaeological interpretations of the period. However, the question about eastern contacts has been discussed in very different ways and from different starting-points when dealing with northern and middle Sweden.

During much of the 20th century, Swedish archaeologists have considered the Mälaren Valley as the active and dominant region in the eastern contact networks, which has affected and influenced regions in the east, although this view has changed in recent research (Hjärthner-Holdar, 1998; Bolin, 2005; Ojala, 2016). Perhaps one of the reasons why eastern contacts have been such an influential model of explanation was that it provided an alternative to the southern Scandinavian Bronze Age and facilitated the image of a distinctive Mälaren Valley Bronze Age identity. On the other hand, throughout the research history, Northern Sweden has mostly been seen as the passive part in the contact networks with areas in the east, and the influences have been seen as coming from the eastern societies, such as from the Ananino cultural region (e.g. Tallgren, 1937). 


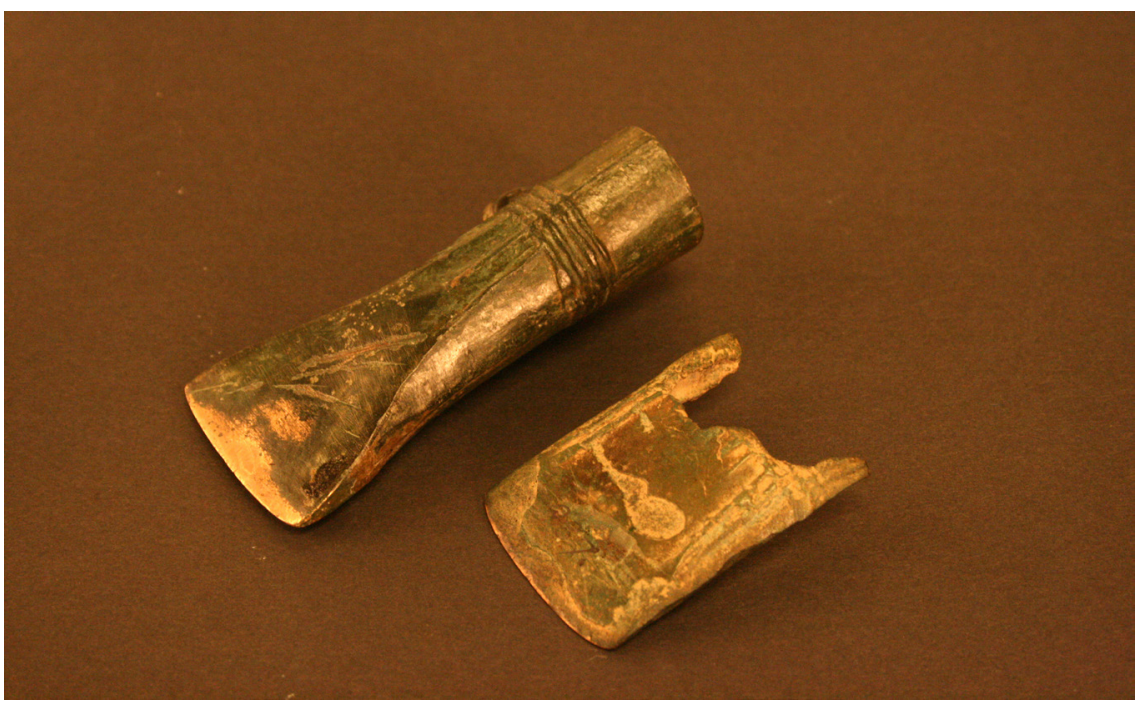

Figure 6: A Mälar axe and an Ananino axe found in the province of Uppland, in middle Sweden. These two types of bronze axes have been connected with the Volga-Kama region in Russia, and have played important roles in discussions on eastern contacts in middle and northern Sweden. Photo by authors. Photo courtesy of Museum Gustavianum, Uppsala University.

Within Sweden, the Mälar axes have been found mainly in Middle Sweden, with a concentration in the Mälaren Valley area. Besides the axes in Russia, some finds of similar axes are also known from Bornholm in Denmark, Norway, Finland and the Baltic countries (Baudou, 1960; Kuzminych, 1993; Yushkova, 2011; Melheim, 2015; Ojala, 2016). In the end of the 19th century, researchers noticed that the distribution pattern of the Mälar axes in Sweden was concentrated to the Mälaren Valley region. It was not until the work of the Finnish archaeologist A. M. Tallgren during the early 20th century that the distribution of the axes in Sweden was connected with the distribution of similar axes in the Volga-Kama region in Russia (Tallgren, 1911). The Mälaren Valley was considered by Tallgren and others to have been a prosperous central region with a wide-ranging network of contacts which stretched across the Baltic Sea to the Volga-Kama region (see e.g. Tallgren, 1911, 1916). Furthermore, it was stated that the influences originated from Sweden (Tallgren, 1916, p. 362; Nerman, 1954).

The question of eastern contacts and influences has continued to be of importance during large parts of the 20th century. In recent years, theories about eastern influences in the Mälaren Valley have been discussed by several archaeologists (see e.g. Kuzminych, 1993, 1996, 2000; Hjärthner-Holdar, 1995, 1998; Feldt, 2004, 2005; Eriksson, 2009). In particular, contacts with areas across the Baltic Sea have been at the focus of recent studies (Wehlin, 2013; cf. Sperling, 2016a, 2016b).

The Ananino axes have a more northern distribution pattern, and have in earlier research mostly been discussed as part of the northern cultural sphere. At least two Ananino axes have been found in the inland parts of northern Sweden (one in Lycksele parish and one in Sorsele parish in the province of Lapland). There are also several finds of moulds for casting Ananino axes in inland northern Sweden. The Ananino axes found in northern Sweden were early related to the Sami population in northern Sweden (Montelius, 1874; see further discussion below). However, one example of an Ananino axe has also been found as far south as in Gamla Uppsala on the outskirts of today's Uppsala. Furthermore, it is worth noting that the only known Ananino axe in Finland has been found in Turku, in the south-west of the country, although several casting moulds for Ananino axes have been discovered in northern and eastern Finland (Huurre, 1986; Lavento, 2019).

In this context, it is interesting to note that recent research on early iron technology in northern Sweden has emphasized connections with areas in the east (Bennerhag, 2012, 2019). In discussions on early iron metallurgy in middle Sweden, influences from eastern areas have also been discussed (Hjärthner-Holdar, 1993, 1998). 
In archaeological research on northern Sweden, notions about eastern contacts and influences, including ideas about migration and the spread of objects and technologies from areas in present-day Russia, have played an important role in theories about the emergence and development of an early Sámi ethnicity. In a very different manner in comparison with the Mälaren Valley, influences from the east have been seen as a more "natural" part of prehistory, concerning different prehistoric periods, from the Stone Age to the Iron Age, even though these contacts seldom, or hardly ever, have been examined more in-depth.

In discussions on the eastern theme, the question concerning the origins and early history of the Sami population has been central. The question of Sámi "origins" has throughout the research history been one of the most discussed issues, and many different theories have been put forth by scholars in different disciplines.

During the early 19th century many scholars considered the Sámi people as the first population in Scandinavia, or even in large parts of northern Europe (see e.g. the work by Sven Nilsson, 1838-1843). However, by the end of the 19th century, the views on early Sámi history changed dramatically, and the Sámi population became understood as a "foreign" people that had immigrated relatively late in history to Scandinavia from some area in the east (e.g. Hallström, 1929; see further Ojala, 2009). During the late 19th century, at a time of growing nationalism and social evolutionist ideas, it became important to separate between what was considered as the national history and that of the others, such as the Sámi, which was considered not to have contributed anything valuable to the national history. Ideas of a Sámi immigration to Scandinavia from the east lived on for a long time in archaeological research in Sweden, at least until the 1970s.

During the 1980s, views on Sámi prehistory underwent major changes. Instead of seeking the answer to when and from where the Sámi had immigrated to northern Scandinavia, scholars started to ask questions about when, where, how and why an early Sámi ethnicity emerged and developed. The change in views took place in connection with the critical debate on the construction of ethnicity in archaeology in the 1980s, and also in connection with the growing Sámi ethnopolitical movement, and ethnic and cultural revitalization movements among Sámi groups from the 1970s (Hesjedal, 2001; Ojala, 2009; Hansen \& Olsen, 2014). However, in these new discussions about an early Sámi ethnicity, eastern contacts still played an important role.

One example is the theory that was put forth by the archaeologist Evert Baudou about a cultural border between Middle Norrland and Upper Norrland (through the northern parts of the provinces of Jämtland and Ångermanland), from about 800 BC onwards (Baudou, 1989, 1995). According to this theory an early Sámi ethnicity developed north of this border, and an early Germanic or Nordic ethnicity south of this border. In this theory, ideas about eastern contacts with the Ananino cultural group in the Volga-Kama region in Russian played a central role, based to a large extent on the distribution patterns of axes and casting moulds of Ananino type. The distribution patterns of asbestos-tempered ceramics, especially so-called asbestos ware, also formed a central argument.

During this period also other scholars, such as the Norwegian archaeologist Bjørnar Olsen, discussed the emergence of an early Sámi ethnicity, in which contacts with societies in the east in present-day Russia were central (Olsen, 1985; cf. also Hansen \& Olsen, 2014). The new discussions on the emergence of an early Sámi ethnicity were inspired by the theories of the social anthropologist Fredrik Barth on ethnic groups and boundaries (Barth, 1969). However, during this period, the "eastern contacts" in archaeological research still played the role of the unknown and unexplored, and the theories that were put forth did not lead to any more in-depth studies of the material culture of the communities in the Volga-Kama region or the character of the long-distance contacts.

In this context, one should also mention that Baudou's theory of a cultural border in the northern part of middle Norrland has subsequently been criticized by several archaeologists - partly based on new archaeological discoveries interpreted as belonging to a Sámi cultural context south of the assumed cultural border - as the theory does not allow for any older Sámi history in the present-day South Sámi region in the provinces of Jämtland, Härjedalen and Dalarna, or in the coastal area in the middle parts of northern Sweden (see e.g. Zachrisson et al., 1997; Ojala, 2009; Broadbent, 2010; cf. also similar discussions on Sámi prehistory in the south on the Norwegian side of the border, e.g. Bergstøl \& Reitan, 2008; Gjerde, 2016). 


\section{Concluding Discussion}

In this article, we have examined the theme of interregional contacts in middle and northern Sweden during the Bronze Age, mainly from a research historical perspective, focusing in particular on the province of Uppland and the coastal areas in northern Sweden. We have argued for the need to explore northern connections in the Nordic Bronze Age sphere. We have also argued that in discussions of northern connections it is also important to examine and analyze eastern contacts with areas in present-day Finland and Russia, and how these contacts have been interpreted in northern and middle Sweden. We have also pointed to the need to critically examine the political dimensions, and power relations, involved in the construction of regional entities and borders in Bronze Age research.

In recent years, new archaeological investigations in the Mälaren Valley region as well as along the coast of northern Sweden have created much new knowledge of the Bronze Age, which have led to a need to rethink contacts between the two areas. While southern influences in the north during the Bronze Age have been an important issue in northern archaeology (with arguments raised for and against), contacts and interactions with the northern areas have seldom been discussed in archaeological research in the Mälaren Valley region. We argue that in order to deepen and nuance the image of the Bronze Age in middle Sweden, especially in Uppland, it is necessary to study relations and interaction with areas further to the north.

By studying "eastern objects", such as bronze axes (e.g. the so-called Mälar axes and Ananino axes), that have been discovered in northern and middle Sweden, another dimension can be added to the understanding of the relations between "north" and "south". We propose that the "eastern objects" are an important key for understanding the relations between northern and middle Sweden during the Bronze Age and the Early Iron Age. The "eastern" bronze axes have been interpreted in very different ways in northern and middle Sweden, which has been connected with different ways of conceptualizing "centers" and "peripheries" in the Bronze Age in middle and northern Sweden. This is especially the case concerning the two regions' perceived relations with the Volga-Kama region in Russia during this time period in earlier research. In earlier scholarly discussions, eastern contacts in northern Sweden have been closely connected with ideas about the emergence of an early Sámi ethnicity, which is highly significant for the understanding of the construction of the border between the Nordic Bronze Age sphere and the northern, "Other", Bronze Age.

For future research, there is a great need to further discuss the content of contacts and the meaning of interactions in the Bronze Age period beyond over-simplified ethnic interpretations and divisions between "north" and "south", and "inland" and "coast". However, it seems that complex cultural and identity processes took place already during the Bronze Age, which later developed to influence the constitution of historically known groups, such as the Sámi, in Northern Fennoscandia.

As discussed in the article, the nation state boundaries in Northern Fennoscandia have been of great importance for the construction of images of the past in the region. There is a great future potential in more developed collaboration between scholars in Sweden, Norway, Finland and Russia, working across the boundaries between different countries and research traditions. Judging from research results from recent years, new cross-boundary archaeological research might have the potential to create much new knowledge and to re-write the histories of northern communities and northern connections in the Bronze Age.

The northern borderlands of the Bronze Age were not any fixed and static endpoints of influences from the south, but active border and meeting zones, with multidirectional influences and contacts, and where complex and dynamic identities developed and transformed. The northern parts of the Nordic Bronze Age sphere was not a periphery, but a dynamic space with many contact networks stretching in different directions.

In our view, it is important to try to look, and work, across the borders between "north" and "south", as well as between "east" and "west", which have delimited and separated archaeological research and images of the past in northernmost Europe. In doing so, it might be possible to challenge and open-up some of the perceived borders in the Bronze Age, and to add new dimensions to the study of contact networks and regional identities in the past. 
Acknowledgements: We would like to thank the Berit Wallenberg Foundation (BWS 2018.0099, project "Bronze Age Coast in the North: Contacts between Middle Sweden and Northern Sweden during the Bronze Age and the Early Iron Age") and also the Gunnar and Birgitta Nordin Foundation. We would also like to thank two anonymous reviewers for constructive comments on an earlier version of the manuscript.

\section{References}

Alberti, M. E., \& Sabatini, S. (2013). Exchange Networks and Local Transformations. Interaction and local change in Europe and the Mediterranean from the Bronze Age to the Iron Age. Oxford: Oxbow Books. https://doi.org/10.2307/j.ctvh1dm19

Almgren, O. (1905). Kung Björns hög och andra fornlämningar vid Håga. Stockholm: Kungl. Vitterhets Historie och Antikvitets Akademien.

Amundsen, H. R. (2017a). Changing histories and ethnicities in a Sámi and Norse borderland. Acta Borealia, 34(2), 178-197. https://doi.org/10.1080/08003831.2017.1398537

Amundsen, H. R. (2017b). Different Bronze Ages: The emergence of diverging cultural traditions in the southern inland, Norway. In S. Bergerbrant \& A. Wessman (Eds.), New perspectives on the Bronze Age: Proceedings of the 13th Nordic Bronze Age Symposium held in Gothenburg 9th to 13th June 2015 (pp. 343-353). Oxford: Archaeopress.

Anfinset, N., \& Wriggelsworth, M. (2012). Introduction: local societies, regions and processes of cultural interaction in the Bronze Age. In N. Anfinset \& M. Wriggelsworth (Eds.), Local Societies in Bronze Age Northern Europe (pp. 1-9). Sheffield: Equinox.

Apel, J., \& Darmark, K. (2007). Mellansvenskt stenhantverk ur ett kulturevolutionistiskt perspektiv. In N. Stenbäck (Ed.), Stenåldern i Uppland. Uppdragsarkeologi och eftertanke (Arkeologi E4 Uppland - Studier 1, pp. 31-66). Uppsala: Riksantikvarieämbetet.

Arbman, H. (1934). Periferisk bronsålderskultur. Fornvännen, 29, 203-212.

Arbman, H. (1938). Mälardalen som kulturcentrum under yngsta bronsåldern. In H. Norling-Christiansen \& P. V. Glob (Eds.), Winther-festskrift (pp. 83-108). København: Munksgaard.

Arntzen, J. E. (2015). Sandvika in northern Norway: The northernmost 'Bronze Age’ settlement in Scandinavia. Fennoscandia Archaeologica, XXXII, 3-34.

Bakka, E. (1976). Arktisk og Nordisk i bronsealderen i Nordskandinavia (Det Kgl. Norske Videnskabers Selskab, Museet, Miscellanea 25). Trondheim: Universitetet i Trondheim.

Barth, F. (1969). Introduction. In F. Barth (Ed.), Ethnic Groups and Boundaries: The Social Organization of Cultural Difference (pp. 9-38). Oslo: Universitetsforlaget.

Baudou, E. (1959). Till fråga om de norrländska kuströsenas datering. Fornvännen, 54, 161-176.

Baudou, E. (1960). Die regionale und chronologische Einteilung der jüngeren Bronzezeit im Nordischen Kreis (Acta Universitatis Stockholmiensis. Studies in North European Archaeology 1). Stockholm: Almqvist \& Wiksell.

Baudou, E. (1968). Forntida bebyggelse i Ångermanlands kustland. Arkeologiska undersökningar av ångermanländska kuströsen. Arkiv för norrländsk hembygdsforskning. XVII, 1-209.

Baudou, E. (1989). Gränser och center-periferi-förhållanden i Norrlands bronsålder. In J. Poulsen (Ed.), Regionale forhold i Nordisk Bronzealder. 5. Nordiske Symposium for Bronzealderforskning på Sandbjerg Slot 1987. Jysk Arkæologisk Selskabs Skrifter XXIV (pp. 175-185). Aarhus: University of Aarhus.

Baudou, E. (1995). Norrlands forntid - ett historiskt perspektiv. Bjästa: CEWE-förlag.

Baudou, E. (2004). Den nordiska arkeologin - historia och tolkningar. Stockholm: Kungl. Vitterhets Historie och Antikvitets Akademien.

Bennerhag, C. (2012). Samhälle i förändring: Järnålder i Norrbottens kustland. Arkeologi i Norr, 13, 45-73.

Bennerhag, C. (2019). Järn i Norr: Tidig järnhantering i jakt- och fångstmiljö under den äldre järnåldern. In P. Moritz (Ed.), Norrbotten 2018-2019: Arkeologi (pp. 139-157). Luleå: Norrbottens museum.

Bergerbrant, S. (2007). Bronze Age Identities: Costume, conflict and Contact in Northern Europe 1600-1300 BC (Stockholm Studies in Archaeology 43). Stockholm: Stockholm University.

Bergstøl, J., \& Reitan, G. (2008). Samer på Dovrefjell i vikingtiden. Et bidrag til debatten omkring samenes sørgrense i forhistorisk tid. Historisk Tidsskrift (Norsk), 87, 9-27.

Bolin, H. (1999). Kulturlandskapets korsvägar. Mellersta Norrland under de två sista årtusendena f.Kr (Stockholm Studies in Archaeology 19). Stockholm: Stockholms universitet.

Bolin, H. (2005). Ockuperad förhistoria - om östligt inflytande i den nordiska bronsålderskretsen. In J. Goldhahn (Ed.), Mellan sten och järn (Part 1, pp. 217-227). Göteborg: Göteborgs universitet.

Broadbent, N. (2001). Fulfilling the Promise... An Essay on Swedish Archaeology and Archaeology in Sweden. Current Swedish Archaeology, 9, 25-38.

Broadbent, N. (2010). Lapps and Labyrinths: Saami Prehistory, Colonization and Cultural Resilience. Washington, D.C.: Smithsonian Institution. 
Christiansson, H. (1963). Norrland och Sydskandinavien: Arkeologiska frågeställningar och problemlösningar under ett sekel. Tor, IX, 9-46.

Damm, C. (2012a). From entities to interaction: Replacing pots and people with networks of transmission. In R. Grünthal \& P. Kallio (Eds.), A Linguistic Map of Prehistoric Northern Europe (Suomalais-Ugrilaisen Seuran Toimituksia 266, pp. 41-62). Helsinki: Suomalais-Ugrilainen Seura.

Damm, C. (2012b). Interaction within and between collectives: Networking in Northern Fennoscandia. In C. Damm (Ed.), Networks, Interaction and Emerging Identities in Fennoscandia and Beyond (pp. 125-138). Helsinki: SuomalaisUgrilainen Seura.

Damm, C., \& Forsberg, L. (2014). Forager-Farmer Contacts in Northern Fennoscandia. In V. Cummings, P. Jordan, \& M. Zvelebil (Eds.), The Oxford Handbook of the Archaeology and Anthropology of Hunter-Gatherers (pp. 838-856). Oxford: Oxford University Press.

Earle, T., Ling, J., Uhnér, C., Stos-Gale, Z., \& Melheim, L. (2015). The Political Economy and Metal Trade in Bronze Age Europe: Understanding Regional Variability in Terms of Comparative Advantages and Articulations. European Journal of Archaeology, 18(4), 633-657. https://doi.org/10.1179/1461957115Y.0000000008

Engedal, Ø. (2010). The Bronze Age of Northwestern Scandinavia. Ph.D. thesis. University of Bergen, Bergen.

Ekholm, G. (1921). Studier i Upplands bebyggelsehistoria II. Bronsåldern. Uppsala universitets årsskrift. Uppsala: Uppsala universitet.

Ekholm, G. (1941). Norrland: En studie i landsdelens äldre bebyggelsehistoria och kulturgeografi. Svensk Geografisk Arsbok, $17,142-168$.

Eriksson, K., Persson, M., \& Ulfhielm, B. (2008). Arkeologisk forskningshistorisk över Gävleborgs län (Rapport Länsmuseet Gävleborg 2008:05). Gävle: Länsmuseet Gävleborg.

Eriksson, T. (2009). Kärl och social gestik. Uppsala: Uppsala universitet.

Fahlander, F. (2018). Bildbruk i mellanrum: Mälarvikens hällbilder under andra årtusendet fvt (Stockholm Studies in Archaeology 76). Stockholm: Stockholms universitet.

Falkenström, P. (2007). Kvarts och Kvartsit. In C. Forsman \& H. Victor (Eds.), Sommaränge Skog: Begravningar, ritualer och bebyggelse från senneolitikum, bronsålder och folkvandringstid (SAU skrifter 18). Uppsala: Societas Archaeologica Upsaliensis.

Feldt, B. (2004). Synliga och osynliga gränser: Förändringar i gravritualen under yngre bronsålder - förromersk järnålder $i$ Södermanland. In A. Åkerlund (Ed.), Kulturell mångfald i Södermanland, Del 2 (pp. 34-43). Nyköping: Länsstyrelsen i Södermanlands län.

Feldt, B. (2005). Synliga och osynliga gränser: Förändringar i gravritualen under yngre bronsålder - förromersk järnålder $i$ Södermanland (Stockholm Studies in Archaeology 37). Stockholm: Stockholms universitet.

Forsberg, L. (1999). The Bronze Age Site at Mårtenfäboda in Nysätra and the Settlement Context of the Cairns on the Coast of North Sweden. In M. Huurre (Ed.), Dig it all. Papers dedicated to Ari Siiriäinen (pp. 251-285). Helsinki: Finnish Antiquarian Society.

Forsberg, L. (2012). Assymetrical twins? Some reflections on coastal and inland societies in the Bothnian area during the Epineolithic and Early Metal Age. In N. Anfinset \& M. Wrigglesworth (Eds.), Local Societies in Bronze Age Northern Europe (pp. 31-53). Sheffield: Equinox.

Forsman, C., \& Victor, H. (2007). Sommaränge skog. Begravningar, ritualer och bebyggelse från senneolitikum, bronsålder och folkvandringstid (SAU Skrifter 18). Uppsala: Societas Archaeologica Upsaliensis.

Gjerde, H. S. (2016). Sørsamisk eller førsamisk? Arkeologi og sørsamisk forhistorie i Sør-Norge: En kildekritisk analyse. PhD thesis. Oslo: University of Oslo.

Gjerde, J. M. (2010). Rock Art and Landscapes: Studies of Stone Age Rock Art from Northern Fennoscandia. PhD thesis. Tromsø: University of Tromsø.

Goldhahn, J. (Ed.). (2005). Från Worm till Welinder: Åtta essäer om arkeologins disciplinhistoriska praxis (Gotarc Serie C. Arkeologiska skrifter No 60). Gothenburg: Gothenburg University.

Hagström Yamamoto, S. (2010). I gränslandet mellan svenskt och samiskt: Identitetsdiskurser och förhistoria i Norrland från 1870-tal till 2000-tal (OPIA 52). Uppsala: Uppsala universitet.

Hallström, G. (1924). Bronsåldersgravar i Medelpad. Fornvännen, 19, 259-280.

Hallström, G. (1929). Kan Lapparnas invandringstid fixeras? En arkeologisk studie. Norrlands försvar, 1929, 40-92.

Hallström, G. (1942). Norrlands bebyggelsehistoria och förhistoriska utveckling. In M. Lundqvist (Ed.), Norrland: Natur, befolkning och näringar (pp. 191-232). Stockholm: Geografiska förbundet i Stockholm \& Industriens utredningsinstitut.

Hallström, G. (1949). Lövångers sockens historia II. In C. Holm (Ed.), Lövånger - En sockenbeskrivning II (pp. 13-89). Umeå.

Hansen, L. I., \& Olsen, B. (2014). Hunters in Transition: An Outline of Early Sámi History. Leiden: Brill. https://doi.org/10.1163/9789004252554

Heinerud, J., \& Larsson, T. (2013). Bronsålderhus vid Umeälvens mynning. Populär Arkeologi, 4, 24-25.

Hermodsson, Ö. (2015). Det arkeologiska landskapet: fornlämningsbild och bebyggelsehistoria i tre uppländska bygder under bronsålder och äldre järnålder. Uppsala: Uppsala universitet.

Hesjedal, A. (2001). Samisk forhistorie i norsk arkeologi 1900-2000 (Stensilserie B 63). Tromsø: University of Tromsø. Hjärthner-Holdar, E. (1993). Järnets och järnmetallurgins introduktion i Sverige (Aun 16). Uppsala: Uppsala universitet. 
Hjärthner-Holdar, E. (1998). Samspel mellan olika regioner i Sverige och Rysland under yngre bronsåldern sett utifrån järnteknologins införande. In T. Løken (Ed.), Bronsealder i Norden - Regioner og interaksjon. Foredrag ved det 7. Nordiske bronsealdersymposium i Rogaland 31. August - 3. September 1995 (AmS-Varia 33, pp. 35-43). Stavanger: Arkeologisk museum i Stavanger.

Hjärthner-Holdar, E., Eriksson, T., \& Östling, A. (Eds.). (2008). Mellan himmel och jord. Ryssgärdet, en guldskimrande bronsåldersmiljö i centrala Uppland (Arkeologi E4 Uppland - Studier Volym 5). Uppsala: Riksantikvarieämbetet.

Holm, J., Olsson, E., \& Weiler, E. (1997). Kontinuitet och förändring i senneolitikum. In M. Larsson \& E. Olsson (Eds.), Regionalt och interregionalt: Stenåldersundersökningar i Syd-och Mellansverige (Riksantikvarieämbetet, Arkeologiska undersökningar 23, pp. 215-264). Stockholm: Riksantikvarieämbetet.

Holm, L., \& Larsson T. B. (2018). Gravrösen i Norrland (UMARK 68). Institutionen för Idé- och Samhällsstudier. Umeå: Umeå universitet.

Holmblad, P. (2010). Coastal communities on the Move. House and Polity Interaction in Southern Ostrobothnia 1500 BC-AD 1 (Archaeology and Environment 26). Umeå: Umeå University.

Hulthén, B. (1991). On ceramic ware in northern Scandinavia during the Neolithic, Bronze and Early Iron Age (Archaeology and Environment 8). Umeå: Umeå universitet.

Huurre, M. (1986). The eastern contacts of northern Fennoscandia in the Bronze Age. Fennoscandia Archaeologica, III, 51-58.

Jaanusson, H. (1981). Hallunda. A studie of Pottery from a Late Bronze Age Settlement in Central Sweden. (The museum of National Antiquities, Studies 1). Stockholm: Historiska museet.

Jensen, C. E., \& Arntzen, J. E. (2016). A Late Bronze Age sheep farm north of the Arctic Circle? In F. Iversen \& H. Petterson (Eds.), The Agrarian life of the north 2000 BC-AD 1000. Studies in rural settlement and farming in Norway (pp. 173-202). Kristiansand: Portal.

Jensen, O. W. (2002). Forntid i historien: En arkeologihistorisk studie av synen på forntiden och forntida lämningar, från medeltid till och med förupplysningen (GOTARC. Serie B. Gothenburg Archaeological Theses no 19). Gothenburg: Gothenburg University.

Kaliff, A., \& Oestigaard, T. (2018). Bronze Age Håga and the Viking King Björn. A History of Interpretation and Documentation from $A D 818$ to 2018 (OPIA 66). Uppsala: Uppsala universitet.

Kristiansen, K. (1987). Center and periphery in Bronze Age Scandinavia. In M. Rowlands, M. Larsen, \& K. Kristiansen (Eds.), Centre and Periphery in the Ancient World (pp. 74-85). Cambridge: Cambridge University Press.

Kristiansen, K. (1998). Europe before History. Cambridge: Cambridge University Press.

Kristiansen, K., \& Larsson, T. B. (2005). The Rise of Bronze Age Society. Travels, Transmissions and Transformations. Cambridge: Cambridge University Press.

Kristiansen, K., \& Suchowska-Ducke, P. (2015). Connected Histories: The Dynamics of Bronze Age Interaction and Trade 1500-1100 BC. Proceedings of the Prehistoric Society, 81, 361-392. https://doi.org/10.1017/ppr.2015.17

Kuusela, J.-M. (2013). Political economy of Bronze and Iron Age societies in the eastern coast of the Bothnian Bay ca. 1500 BC$A D$ 1300. Ph.D. thesis. Oulu: University of Oulu.

Kuusela, J.-M., Nurmi, R., \& Hakamäki, V. (2018). Unhierarchical and Hierarchical Core-Periphery Relations: North Fennoscandian Trade Network from the Middle Ages to the Post-Sixteeth Century. American Anthropologist, 120(4), 765-780. https://doi.org/10.1111/aman.13104

Kuzminych, S. V. (1993). Melarskie kel'ty Vostochnoi Evropy i Fennoskandii: k probleme odnoi arkheologicheskoi zagadki [Mälar axes of Eastern Europe and Fennoscandia: on the problem of an archaeological riddle]. Arkheologicheskie pamiatniki srednego pooch'ia, 3, 61-107. [in Russian]

Kuzminych, S. V. (1996). Osteuropäische und Fennoscandische Tüllenbeile des Mälartyps: Ein Rätsel der Archäologie. Fennoscandia Archaeologica, XIII, 3-27.

Kuzminych, S. V. (2000). Arkheologicheskoe izuchenie anan'inskogo mira v XX veke: osnovnye dostizheniia i problemy [The archaeological study of the Ananino world in the 20th century: main achievements and problems]. In R. D. Goldina (Eds.), Rossiiskaia arkheologiia: dostizheniia XX i perspektivy XXI vv. [Russian archaeology: achievements of the 20th century and perspectives for the 21st century] (pp. 104-113). Izhevsk: Udmurtskii gosudarstvennyi universitet. [in Russian]

Larsson, T. B. (1986). The Bronze Age Metalwork in Southern Sweden: Aspects of Social and Spatial Organization 1800-500 B.C. (Archaeology and Environment 6). Umeå: Umeå University.

Larsson, T. B. (2017). Metallföremål från bronsåldern i Norrland (UMARK 67). Umeå: Umeå universitet.

Lavento, M. (2001). Textile ceramics in Finland and on the Karelian Isthmus (Suomen muinaismuistoyhdistyksen aikakauskirja 109). Helsingfors: Suomen muinaismuistoyhdistys.

Lavento, M. (2009). Kan man använda begreppet bronsålder i Finland? In T. Brattli (Ed.), Det 10. Nordiske bronsealdersymposium. Trondheim 5.-8. Okt. 2006 (VITARK 6, pp. 124-135). Trondheim: Tapir.

Lavento, M. (2012). Local centres in the periphery: the Late Neolithic, Bronze Age and Early Metal Age in Finland. In N. Anfinset \& M. Wrigglesworth (Eds.), Local Societies in Bronze Age Northern Europe (pp. 148-168). Sheffield: Equinox.

Lavento, M. (2019). Early Metal Age bronze axes in Finland: An overview. [Transactions of the Institute for the History of Material Culture RAN]. Zapiski Institut Istorii Materialnoj Kultury RAN, 20, 35-52. https://doi.org/10.31600/2310-65572019-20-35-52 
Lindqvist, S. (1913). De svenska holkyxorna från bronsåldern. Opuscula archaeologica Oscar Montelio. Septuagenario dicata D. IX M. SEPT. A. MCMXII (pp. 79-90). Stockholm: Ivar Hæggström.

Lindqvist, A.-K., \& Granholm, N. (2016). Stolpbyggda hus vid Umeälvens mynning. Den yngre bronsåldern i ny skepnad. Arkeologi i Norr, 15, 37-62.

Ling, J. (2013). Rock Art and Seascapes in Uppland. Oxford \& Oakville: Oxbow Books.

Ling, J., Earle, T., \& Kristiansen, K. (2018). Maritime mode of production: Raiding and trading in seafaring chiefdoms. Current Anthropology, 59(5), 488-524. https://doi.org/10.1086/699613

Ling, J., Hjärthner-Holdar, E., Grandin, L., Stos-Gale, Z., Kristiansen, K., Melheim, A. L., . . Canovaro, C. (2019). Moving metals IV: Swords, metal sources and trade networks in Bronze Age Europe. Journal of Archaeological Science, Reports, 26, 101837. https://doi.org/10.1016/j.jasrep.2019.05.002

Loeffler, D. (2005). Contested Landscapes/Contested Heritage: history and heritage in Sweden and their archaeological implications concerning the interpretation of the Norrlandian past (Archaeology and Environment 18). Umeå: Umeå University.

Meinander, C. F. (1985). Akozino, Achmylovo och mälaryxorna. Finskt Museum, 92, 15-34.

Melheim, L. (2015). Late Bronze Age traffic from Volga-Kama to Scandinavia? The riddle of the KAM axes revisited. In A. Hauptmann \& D. Modarressi-Tehrani (Eds.), Archaeometallurgy in Europe III. Proceedings of the 3rd International Conference Deutsches Bergbau-Museum Bochum. June 29 - July 1, 2011. Der Anschnitt. Zeitschrift für kunst und kultur im Bergbau (Beiheft 26, pp. 193-202). Bochum.

Montelius, O. (1871-1873). Bronsålder i norra och mellersta Sverige. Antiqvarisk tidskrift för Sverige. Utgifven af Kongl. Vitterhets historie och antiqvitets akademin, 3, 173-433.

Montelius, O. (1874). En bronscelt funnen i Lappland. Kongl. Vitterhets Historie och Antiqvitets Akademiens Månadsblad, 1874, 145-147.

Montelius, O. (1917). Minnen från vår forntid/ordnade och beskrifna af Oscar Montelius. Stenåldern och bronsåldern. Stockholm: Norstedt.

Nerman, B. (1954). Yngre bronsåldern - en första svensk vikingatid. Fornvännen, 49, 257-285.

Nilsson, S. (1838-1843). Skandinaviska nordens ur-invånare: ett försök $i$ komparativa ethnografien och ett bidrag till menniskoslägtets utvecklingshistoria. Lund.

Ojala, C.-G. (2009). Sámi Prehistories: The Politics of Archaeology and Identity in Northernmost Europe. Uppsala: Uppsala University.

Ojala, C.-G. (2014). East and West, North and South in Sápmi: Networks and boundaries in Sámi archaeology in Sweden. In J. Ikäheimo, A.-K. Salmi, \& T. Äikäs (Eds.), Sounds Like Theory (Monographs of the Archaeological Society of Finland 2, pp. 173-185). Helsinki: Archaeological Society of Finland.

Ojala, C.-G. (2017). Contested colonial history and heritage in Sápmi: Archaeology, indigeneity and local communities in Northern Sweden. In Ch. Hillerdal, A. Karlström, \& C.-G. Ojala (Eds.), Archaeologies of "Us" and "Them": Debating History, Heritage and Indigeneity (pp. 258-271). London, New York: Routledge.

Ojala, C.-G. (2018). Encountering 'the Other' in the North: Colonial histories in early modern northern Sweden. In M. Naum \& F. Ekengren (Eds.), Facing Otherness in Early Modern Sweden: Travel, migration and material transformations, 1500-1800 (Society for Post-Medieval Archaeology Monograph 10, pp. 209-228). Woodbridge: Boydell Press.

Ojala, C.-G. (2019). Discussion: Colonialism Past and Present - Archaeological Engagements and Entanglements. In T. Äikäs. and A-K. Salmi (Eds.), The Sound of Silence: Indigenous Perspectives on the Historical Archaeology of Colonialism (pp. 182-201). New York: Berghahn Books.

Ojala, C.-G., \& Nordin, J. M. (2015). Mining Sápmi: Colonial Histories, Sámi Archaeology, and the Exploitation of Natural Resources in Northern Sweden. Arctic Anthropology, 52(2), 6-21. https://doi.org/10.3368/aa.52.2.6

Ojala, C.-G., \& Nordin, J. M. (2019). Mapping land and people in the North: Early modern colonial expansion, exploitation and knowledge. Scandinavian Studies, 91(1-2), 98-133. https://doi.org/10.5406/scanstud.91.1-2.0098

Ojala, K. (2016). I bronsålderns gränsland. Uppland och frågan om östliga kontakter (OPIA 61). Uppsala: Uppsala universitet.

Olausson, M. (1995). Det inneslutna rummet: Om kultiska hägnader, fornborgar och befästa gårdar i Uppland från 1300 f.Kr. till Kristi födelse (Arkeologiska undersökningar, Skrifter nr 9). Stockholm: Riksantikvarieämbetet.

Oldeberg, A. (1933). Det nordiska bronsåldersspännets historia: Med särskild hänsyn till dess gjuttekniska utformning $i$ Sverige. Stockholm: Kungl. Vitterhets, Historie och Antikvitets Akademien.

Olsen, B. (1985). Comments on Saamis, Finns and Scandinavians in history and prehistory. Norwegian Archaeological Review, 18(1-2), 13-18. https://doi.org/10.1080/00293652.1985.9965405

Palmbo, F. (2019). Bronsålder i Norrbottens kustland. In P. Moritz (Ed.), Norrbotten 2018-2019: Arkeologi (pp. 109-137). Luleå: Norrbottens museum.

Persson, P. (2018). Forntid i Västernorrlands län: En historik över arkeologiska undersökningar under drygt 330 år. Härnösand: Västernorrlands museum.

Ramqvist, P. H. (2007). Fem Norrland: Om norrländska regioner och deras interaktion. Arkeologi i Norr, 10, 153-180.

Ramqvist, P. H. (2017). Om äldre gravskick i det norrländska kustområdet. Arkeologi i Norr, 16, 87-110. 
Rowlands, M., \& Ling, J. (2013). Boundaries, flows and connectivities: Mobility and stasis in the Bronze Age. In S. Bergerbrant \& S. Sabatini (Eds.), Counterpoint: Essays in Archaeology and Heritage Studies in Honour of Professor Kristian Kristiansen (BAR International Series: Vol. 2508, pp. 517-529). Oxford: Archaeopress.

Schönbäck, B. (1959). Bronsåldersbygd i Mälarområdet. Tor, V, 52-107.

Skandfer, M., \& Wehlin, J. (2017). The northern perspective 2000 BC - AD 1. In S. Bergerbrant \& A. Wessman (Eds.), New perspectives on the Bronze Age: Proceedings of the 13th Nordic Bronze Age Symposium held in Gothenburg 9th to 13th June 2015 (pp. 307-312). Oxford: Archaeopress.

Skoglund, P., Ling, J., \& Bertilsson, U. (Eds.). (2017). North meets south: Theoretical aspects on the northern and southern rock art traditions in Scandinavia. Oxford: Oxbow. https://doi.org/10.2307/j.ctvh1dpgg

Sperling, U. (2016a). Visitors to the other side: some reflections on the Baltic Sea as a frontier and contact zone in late prehistory. In A. Kannike \& M. Tasa (Eds.), The Dynamics of Cultural borders (pp. 106-132). Tartu: University of Tartu Press.

Sperling, U. (2016b). Bronze Age Connections across the Baltic Sea: Discussing Metalwork as Source of Maritime Contacts in Prehistory. In H. B. Bjerck, H. M. Breivik, S. E. Fretheim, E. L. Piana, B. Skar, A. M. Tivoli, \& A. F. J. Zangrando (Eds.), Marine Ventures: Archaeological Perspectives on Human-Sea Relations (pp. 399-416). Sheffield: Equinox.

Stenberger, M. (1964). Det forntida Sverige. Stockholm: Almqvist \& Wiksell.

Suchowska-Ducke, P., Reiter, S., \& Vandkilde, H. (Eds.). (2015). Forging Identities. The Mobility of Culture in Bronze Age Europe. Report from a Marie Curie Project 2009-2012 with Concluding Conference at Aarhus University, Moesgaard 2012 (Vol. 1 \& Vol. 2, Bar International Series 2771). Oxford: British Archaeological Reports.

Tallgren, A. M. (1911). Die Kupfer- und Bronzezeit Nord- und Ostrussland. Helsinki: University of Helsinki.

Tallgren, A. M. (1916). Sveriges förbindelser med Ryssland under bronsåldern. Finsk Tidskrift, 80, 362-374.

Tallgren, A. M. (1937). The Arctic Bronze Age in Europe. Eurasia Septentrionalis Antiqua, XI, 1-46.

Thedéen, S. (2004). Gränser i livet - gränser i landskapet. Generationsrelationer och rituella praktiker i södermanländska bronsålderslandskap (Stockholm Studies in Archaeology 33). Stockholm: Stockholms universitet.

Tuovinen, T. (2002). The burial cairns and the landscape in the archipelago of Åboland, sw Finland, in the Bronze Age and the Iron Age (Acta Universitatis Ouluensis B 46). Oulu: Oulu University Press.

Ullén, I., \& Drenzel, L. (2018). Återbesök i Hågahögen - nya analysresultat. Fornvännen, 113, 121-138.

Vandkilde, H. (2016). Bronzization: The Bronze Age as Pre-Modern Globalization. Praehistorische Zeitschrift, 91(1), 103-123. https://doi.org/10.1515/pz-2016-0005

Victor, H. (2002). Med graven som granne: Om bronsålderns kulthus. Aun 30. Uppsala: Uppsala universitet.

Victor, H. (2007). Skärvstensbruk och skärstenskult - ett utryck för regionalitet och kosmologi. In M. Notelid (Ed.), Att nå den andra sidan. Om begravningar och ritual i Uppland. Arkeologi E4 Uppland - studier (Vol. 2, pp. 235-254). Uppsala: Riksantikvarieämbetet.

Wehlin, J. (2013). Östersjöns skeppssättningar: Monument och mötesplatser under yngre bronsålder. Göteborg: Göteborgs universitet.

Wehlin, J. (2017). Gravar och identitet i bronsålderns periferi. Arkeologi i norr, 16, 55-86.

Zachrisson, I., Alexandersen, V., Gollwitzer, M., Iregren, E., Königsson, L.-K., Siven, C.-H. Strade, N. \& Sundström J. (1997). Möten i Gränsland. Samer och germaner i Mellanskandinavien (Monographs 4). Stockholm: Statens Historiska Museum.

Yushkova, M. A. (2011). Novye nakhodki metallicheskikh izdelii epokhi bronzy na severo-zapade Rossii [New finds of metal objects from the Bronze Age in north-western Russia]. Tverskoi Arkheologicheskii sbornik, 8(1), 273-288. [in Russian] 